\title{
260 非線形ばねで支持された粘弾性ブロックの振動減衰特性の有限要素解析
}

Vibration Analysis of Damping Properties for a Viscoelastic Block Supported by a Nonlinear Spring Using FEM

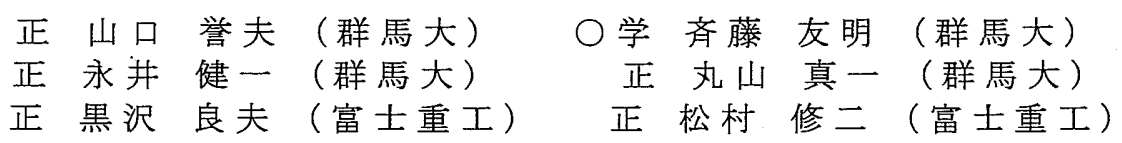

Takao YAMAGUCHI, Gunma University, 1-5-1 Tenjin-cho, Kiryu-shi, Gunma

Tomoaki SAITO, Gunma University

Ken-ichi NAGAI, Gunma University

Shinichi MARUYAMA, Gunma University

Yoshio KUROSAWA, FUJI HEAVY INDUSTRIES

Shuji MATSUMURA, FUJI HEAVY INDUSTRIES

This paper describes vibration analysis using finite element method for a viscoelastic block supported by a nonlinear concentrated spring. The restoring force of the spring has cubic nonlinearity and linear hysterisis damping. Finite element for the nonlinear spring is expressed and is connected to the viscoelastic block modeled by linear solid finite elements in consideration with complex modulus of elasticity. Further, the discretized equations in physical coordinate are transformed into the nonlinear ordinary coupled equations using normal coordinate corresponding to linear natural modes. This transformation yields computation efficiency. Influences of share of dissipated energy on nonlinear frequency responses for the viscoelastic block are clarified.

Key Words : Computer Aided Analysis,Finite Element Method, Nonlinear Vibration, Vibration of Continuous System, Damping

\section{A 1. 緒言}

線形ヒステリシス減衰を有する非線形集中ばねで支持さ れた粘弾性ブロックの動的応答を解析した. 集中ばねの有 限要素を定式化し,ブロックの離散化方程式と接合した. 運動方程式を, 線形固有振動形を基準座標とする三次の非 線形連立常微分方程式に変換し, 計算自由度を縮小した。

\section{A 2. 解析モデル}

非線形集中ぼねを接続した粘弾性ブロックのモデルを図 A1 に示す. 図中の剛なガイドを設置し, ブロックのガイド 面に法線方向の運動を拘束した. 集中ばねは、三次の非線 形復元項を有する漸硬ばねとした. この特性に線形ヒステ リシス減衰を与え計算した.

\section{A 3. 基礎式}

図A1のような粘弾性ブロックー非線形集中ばね系の有 限要素による離散化方程式を求める. 物理座標系の離散化 方程式を, 線形固有振動形 $\left\{\phi^{(i)}\right\}$ に対応する基準座標 $b_{i}$ の 全系の離散化運動方程式に変換し, 次式を得る.

$$
\begin{aligned}
& \ddot{b}_{i}+\eta_{\mathrm{tot}}^{(i)} \omega^{(i)} \dot{b}_{i}+\left(\omega^{(i)}\right)^{2} \bar{b}_{i}+\sum_{j} \sum_{k} D_{i j k} \bar{b}_{j} \bar{b}_{k} \\
& +\sum_{j} \sum_{k} \sum_{i} E_{i j k l} b_{j} \bar{b}_{k} \bar{b}_{l}-P_{i}=0 \\
& \tilde{D}_{i j k}=\gamma_{2} \frac{n_{i}}{n_{j} n_{k}} \tilde{\phi}_{\alpha i x} \tilde{\phi}_{\alpha j x} \tilde{\phi}_{\alpha k x} \text {, } \\
& \hat{E}_{i j k l}=\gamma_{3} \frac{n_{i}}{n_{j} n_{k} n_{l}} \hat{\phi}_{\alpha i x} \hat{\phi}_{\alpha j x} \hat{\phi}_{\alpha k x} \hat{\phi}_{\alpha / x} \text {, } \\
& \stackrel{P}{P}_{i}=n_{i}\left\{\phi^{(i)}\right\}_{0}^{\mathrm{T}}\{f\} \text {, } \\
& \left\{\tilde{\phi}^{(i)}\right\}_{(i=1}=\left\{\tilde{\phi}_{1 i x}, \hat{\phi}_{1 i y}, \tilde{\phi}_{1 i z}, \tilde{\phi}_{2 i x}, \tilde{\phi}_{2 i y}, \tilde{\phi}_{2 i z}, \hat{\phi}_{3 i x}, \cdots\right\}^{\mathrm{T}} \\
& (i=1,2,3 \ldots, j=1,2,3 \ldots k=1,2,3 \ldots .=1,2,3 \ldots,) \\
& \text { Origin }
\end{aligned}
$$

Fig.A1 Schematic model for numerical analysis
ただし,節点変位ベクトル $\{u\}$ を $i$ 次の線形固有振動数

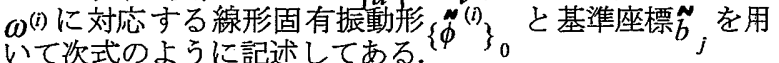

$$
\{u\}=\sum_{i=1} \tilde{b}_{i} \frac{1}{n_{i}}\left\{\delta^{(i)}\right\}_{0} \ldots \ldots \ldots \ldots \ldots \ldots \text { (A2) }
$$

また, $\gamma_{2}, \gamma_{3}$ はそれぞれ非線形集中ばねの 2 次および 3 次のばね定数である. $\{f\}$ は外力ベクトルである. $\eta_{\text {tot }}^{(i)}$ は $i$ 次のモード損失係数であり, 減衰パラメータを漸近展 開し, 微小振幅の運動方程式に代入して微小量の 1 次まで を考慮することで求めた. $\hat{\phi}_{\alpha i x}$ は集中ばねとブロックの接 合節点 $\alpha$ における $x$ 方向の $\left\{\tilde{\phi}^{(i)}\right\}_{0}$ の成分である. 式 (A1) の 解を仮定し, 調和バランス法を用いて共振応答を求めた.

\section{A 4. 結果と結言}

非線形集中ばね, 粘弾性ブロックの材料損失係数を $\eta_{s}=0.01, \eta_{b}=0.2$ とし, ブロックのヤング率 $E$ が異なる場 合の共振応答を図 A2 (a) と図 A2（b）に示す. 近似モード数 は $I c=20$ とした. ブロックのヤング率 $E$ が大きい場合, 最 低次の共振応答曲線が漸硬型となる.さらに, 最低次の共 振の 3 倍高調波共振と $1 / 3$ 分数次調波共振が新たに現れ る.ヤング率 $E$ が小さい場合，ばね変形が主体の振動モー ドにブロック弹性変形が含まれ, 1 次モードの減衰 (モー ド損失係数 $\left.\eta_{\mathrm{tot}}^{(1)}\right)$ が大きくなる.その減衰増大の効果によ り，最低次の共振の 3 倍高調波共振がジャンプしなくなる とともに $1 / 3$ 分数次調波共振が認められなくなる.

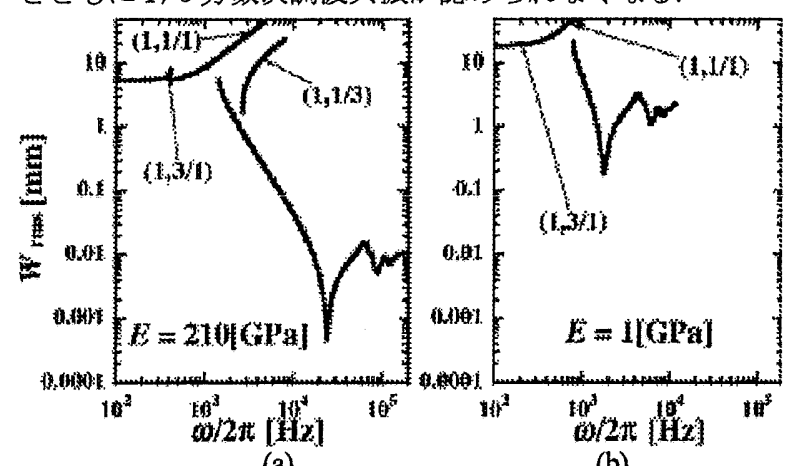

(a)

(b)

Fig.A 2 Effects of Young's modulus on resonance response

日本機械学会 〔No.04-5〕 Dynamics and Design Conference 2004 CD-ROM論文集 〔2004.9.27-30,東京〕 


\section{1. 緒 言}

機械構造物を集中ぼねで支持し振動絶縁することがあ る.防振要素には荷重と変位の間に非線形性を持つものも ある。一方, 機械構造物は一般に弾性体であり, 弹性体と非 線形ばねを接続した問題の解明が重要である.著者らは構 造物を線形有限要素により弾性体としてモデル化し, 非線 形集中ばねで支持した系の連成振動解析を行ってきた ${ }^{(1)}$. 本論では, 線形ヒステリシス減衰を有する非線形集中ばね で粘弾性ブロックを支持し, 鉛直方向の周期加振力を加え 動的応答を解析する.また, ブロックと集中ばねの散逸エ ネルギー分担量を解析し, 共振応答への影響を検討した.

\section{2. 解析モデル}

非線形集中ばねを接続した粘弾性ブロックのモデルを図 1 に示す. 粘弾性ブロックは微小変形を仮定し, さらに複 素弾性率を導入した有限要素法を用いた. 図中の剛なガイ ドを設置し,ブロックのガイド面に法線方向の運動を拘束 した. 減衰を考慮しない条件での非線形集中ばねの復元力 $R_{\alpha x}$-変位 $U_{\alpha, x}$ 曲線を図 2 に示す. 三次の非線形復元項を有 する漸硬ばねとした。この特性に線形ヒステリシス減衰を 与え以降の計算を行った。

\section{3. 基礎式}

図1のように粘弾性ブロックに非線形集中ばねが接続 される場合を考える.この系の有限要素による離散化方程 式を求める.

3. 1 非線形集中ばねの離散化方程式非線形集中ばね は図 1 の方向に弾性主軸を有するとする.非線形集中ば ねと粘弹性ブロックが接合される節点 $\alpha$ の $x$ 方向変位を $U_{\alpha x}$ とおく.ばねによる節点力 $R_{\alpha x}$ が次式で与えられる場 合を考える.

$R_{\alpha x}=\gamma_{1} U_{\alpha x}+\gamma_{2} U_{\alpha x}^{2}+\gamma_{2} U_{\alpha x}^{3}$

ただし，この集中ばねには線形ヒステリシス隇衰を導入
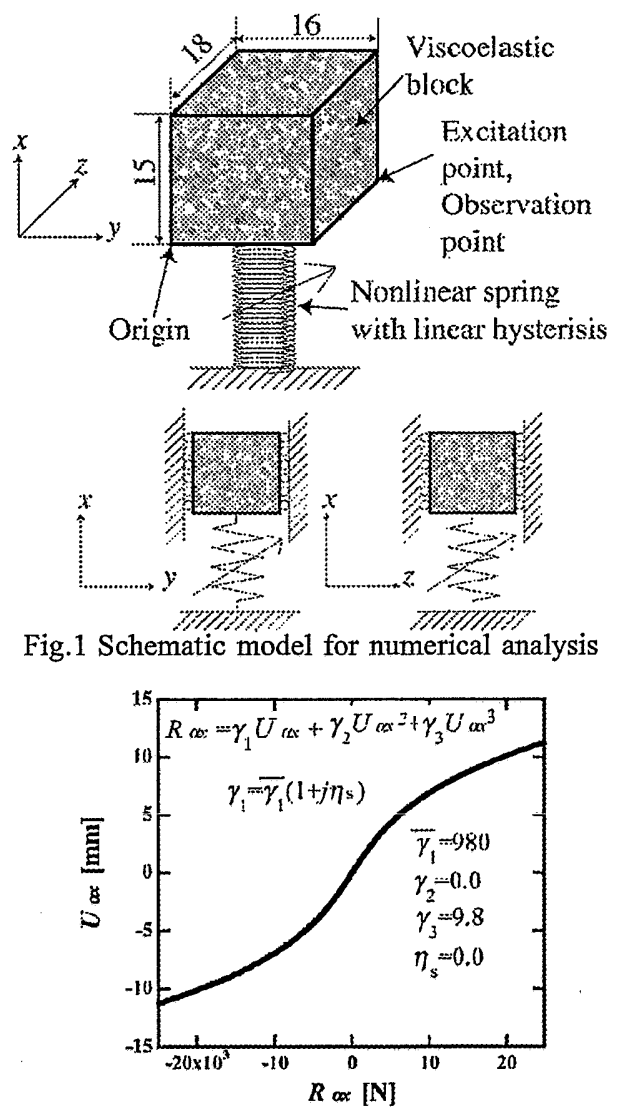

Fig.2 Restoring force of nonlinear concentrated spring
し $\gamma_{1}=\gamma_{1}\left(1+j \eta_{s}\right)$ とする.ここで, $\gamma_{1}$ は $\gamma_{1}$ の実数部, $\eta_{s}$ は 集中ばねの材料損失係数, $j$ は虚数単位である.この関係を マトリックスで記述すると次式となる.

$$
\{r\}=\left[\gamma_{1}\right]\left\{U_{s}\right\}+\{d\}
$$

ここで,

$$
\begin{aligned}
& \{r\}=\left\{R_{\alpha x x} R_{\alpha y} R_{\alpha z}\right\}^{\mathrm{T}}, \quad\left\{U_{s}\right\}=\left\{U_{\alpha x} U_{\alpha y} U_{\alpha z}\right\}^{\mathrm{T}}, \\
& {\left[\bar{\gamma}_{1}\right]=\left[\begin{array}{ccc}
\gamma_{1} & 0 & 0 \\
0 & 0 & 0 \\
0 & 0 & 0
\end{array}\right],\{\bar{d}\}=\left\{\begin{array}{c}
\gamma_{2} U_{\alpha x}^{2}+\gamma_{3} U_{\alpha x}^{3} \\
0 \\
0
\end{array}\right\},} \\
& R_{\alpha y}=R_{\alpha z}=0
\end{aligned}
$$

である.

3. 2 粘弾性ブロックの離散化方程式 ブロックは三次 元有限要素で分割する.ブロックには微小変形を仮定し線 形三次元有限要素を用いる. 要素内部の変位ベクトルを $\left\{U_{b}\right\}=\left\{U_{x}, U_{y}, U_{z}\right\}^{\mathrm{T}}$ とおき, $\left\{U_{b}\right\}$ を節点変位べクトル $\left\{U_{e}\right\}$ と形状関数 $[N]^{\mathrm{T}}$ で次式のように近似する.

$\left\{U_{b}\right\}=[N]^{\mathrm{T}}\left\{U_{e}\right\}$

非適合モードを考慮した 8 節点 isoparametric solid 要素でブロックをモデル化した ${ }^{(2) .(3) . ~}$

応力ベクトル $\{\sigma\}$ と歪みベクトル $\{\varepsilon\}$ との関係は, 次式 となる.

$$
\{\sigma\}=[D]\{\varepsilon\}
$$

$[D]$ はヤング率とポアソン比で構成される. $\left\{U_{b}\right\}$ と歪み ベクトル $\{\varepsilon\}$ との関係は次式となる.

$\{\varepsilon\}=[A]\left\{U_{b}\right\}=[B]\left\{U_{e}\right\}$

$$
[A]=\left[\begin{array}{ccc}
\frac{\partial}{\partial x} & 0 & 0 \\
0 & \frac{\partial}{\partial y} & 0 \\
0 & 0 & \frac{\partial}{\partial z} \\
\frac{\partial}{\partial y} & \frac{\partial}{\partial x} & 0 \\
0 & \frac{\partial}{\partial z} & \frac{\partial}{\partial y} \\
\frac{\partial}{\partial z} & 0 & \frac{\partial}{\partial x}
\end{array}\right],[B]=[A][N]
$$

要素の歪みエネルギー UN, 運動エネルギーN , ポテンシャ ルエネルギー尚を求め, ラグランジェの方程式からブロッ クの要素の離散化方程式を次式から得る.

$$
\begin{aligned}
& {\left[M_{e}\right]\left\{\ddot{u}_{e}\right\}+\left[K_{e}\right]\left\{u_{e}\right\}=\left\{f_{e}\right\} \cdots} \\
& {\left[M_{e}\right]=\iiint_{e} \rho_{e}[N][N]^{\mathrm{T}} d x d y d z} \\
& {\left[K_{e}\right]=\iiint_{e}[B]^{\mathrm{T}}[D][B] d x d y d z}
\end{aligned}
$$

ここで, $\iiint_{e} d x d y d z$ は要素領域内での積分を表す. $\left[M_{e}\right],\left[K_{e}\right],\left\{u_{e}\right\},\left\{f_{e}\right\}$ はそれぞれブロックの要素質量行 列, 要素剛性行列, 要素内の節点変位ベクトル, 要素内の節 点力ベクトルである. $\rho_{e}$ は要素 $e$ の質量密度である.また, 式中の・は時間微分を表す.

粘弾性特性を考慮するためにブロックの弾性率 $E$ を複 素弾性率 $\left(E=E\left(1+j \eta_{b}\right), E\right.$ : 弾性率の実部, $\eta_{b}$ :ブロッ クの材料損失係数) とする, その結果, 式 (4) 中の $[D]$ 複 素数となり，さらに式 (7), 式 (9) 中の要素剛性行列 $\left[K_{e}\right]$ も複素行列となる. 
ブロック全系で要素方程式を重ね合わせると次式を得る. $\left[M_{b}\right]\left\{\ddot{u}_{b}\right\}+\left[K_{b}\right]\left\{u_{b}\right\}=\left\{f_{b}\right\} \ldots \ldots \ldots \ldots \ldots$ (10)

$\left[M_{b}\right],\left[K_{b}\right],\left\{f_{b}\right\},\left\{u_{b}\right\}$ はブロック全系の質量行列, 複 素剛性行列, 節点力ベクトル, 変位ベクトルである.

3.3 粘弾性ブロックを集中ばねに接続した系の離散化方 程式 式 (2)の $\{r\}$ を式 (10) 中の粘弾性ブロックと 非線形ばねの接合節点 $\alpha$ の節点力に加え全系の離散化方 程式を得る。

$[M]\{\ddot{u}\}+[K]\{u\}+\{d\}=\{f\}$

ただし, $\{u\},[M],[K],\{f\}$ は全系の変位ベクトル, 質量行 列, 複素剛性行列, 節点力ベクトルである. $\{\hat{d}\}$ は $\{\bar{d}\}$ を 全系のサイズに変換したベクトルである.

3.4 モード減衰の近似計算 式 (11) で外力項, 非 線形復元力項を $\{0\}$ とし $\{u\}=\{\phi\} \exp (j \omega t)$ を仮定する と, 次の複素固有値問題の式を得る.

$$
\sum_{e=1}^{e}\left(\left[K_{\mathrm{R}}\right]_{e}\left(1+j \eta_{e}\right)-\left(\omega^{(i)}\right)^{2}\left(1+j \eta_{\mathrm{tot}}^{(n)}\right)[M]_{e}\right)\left\{\phi^{(i)}\right\}
$$$$
=\{0\}
$$

$\left[K_{R}\right]_{e}$ は要素剛性行列の実数部, $[M]_{e}$ は要素質量行列で ある. 添え字 $(i)$ は $i$ 次振動モ一ド, $\left(\omega^{(i)}\right)^{2}$ は複素固有値の 実部, $\left\{\phi^{(i)}\right\}$ は複素固有モード, $\eta_{\mathrm{tot}}^{(i)}$ はモード損失係数, $e_{\max }$ は要素数である.

材料減衰 $\eta_{e},\left(e=1,2,3, \ldots, e_{\text {max }}\right)$ に関し全要素の中 で最大のものを $\eta_{\max }$ とする. また, 以下の $\beta_{e}$ を導入する.

$$
\beta_{e}=\eta_{e} / \eta_{\max }, \beta_{e} \leq 1 \ldots \ldots \ldots \ldots \ldots \text { (13) }
$$

ここで $\eta_{\max } \ll 1$ と仮定し, 微少量 $\mu=j \eta_{\max }$ を導入し, 式 (12) の解を漸近展開すると, 次式を得る.

$\left\{\phi^{(i)}\right\}=\left\{\phi^{(i)}\right\}_{0}+\mu\left\{\phi^{(i)}\right\}_{1}+\mu^{2}\left\{\phi^{(i)}\right\}_{2}+\ldots \ldots \cdots(14)$

$\left(\omega^{(i)}\right)^{2}=\left(\omega_{0}^{(i)}\right)^{2}+\mu^{2}\left(\omega_{2}^{(i)}\right)^{2}+\mu^{4}\left(\omega_{4}^{(i)}\right)^{2}+\ldots \ldots$ (15)

$j \eta_{\text {tot }}^{(i)}=\mu \eta_{1}^{(i)}+\mu^{3} \eta_{3}^{(i)}+\mu^{5} \eta_{5}^{(i)}+\mu^{7} \eta_{7}^{(i)}+\ldots \ldots$ (16)

ただし, $\beta_{e} \leq 1$ であるので $\eta_{\max } \beta_{e}<<1$ が成立し $\mu \beta_{e}$ も $\mu$ と同様に微少量となる. $\left\{\phi^{(i)}\right\}_{0},\left\{\phi^{(i)}\right\}_{1},\left\{\phi^{(i)}\right\}_{2} \ldots$ 之 $\left(\omega_{0}^{(i)}\right)^{2},\left(\omega_{2}^{(i)}\right)^{2},\left(\omega_{4}^{(i)}\right)^{2}, \ldots$ および $\eta_{1}^{(i)}, \eta_{3}^{(i)}, \eta_{5}^{(i)} \ldots$ は実 数とする.

ついで式 (14) 式 (15) 式 (16) を式 (12) に代入し, $\mu^{0}$ と $\mu^{1}$ の量ごとにまとめると次式を得る.

$\mu 0$ の量:

$$
\begin{aligned}
& \sum_{e=1}^{e \max }\left(\left[K_{R}\right]_{e-}\left(\omega_{0}^{(i)}\right)^{2}[M]_{e}\right)\left\{\phi^{(i)}\right\}_{0}=\{0\} \cdots(17) \\
& \sum_{e=1}^{e}\left(\mu \beta_{e}\left[K_{R}\right]_{e}-\mu \eta_{1}{ }^{(i)}\left(\omega_{0}{ }^{(i)}\right)^{2}[M]_{e}\right)\left\{\phi^{(i)}\right\}_{0} \\
& +\sum_{e=1}^{e}\left(\mu\left[K_{R}\right]_{e}-\mu\left(\omega_{0}{ }^{(i)}\right)^{2}[M]_{e}\right)\left\{\phi^{(i)}\right\}_{1}=\{0\} \cdots
\end{aligned}
$$

$\eta_{\text {tot }}^{(i)}=\sum_{e=1}^{e} \eta_{e} S_{e}^{(i)}$

ただし, $S_{e}^{(i)}=\left\{\phi^{(i)}\right\}_{0}^{\mathrm{T}}\left[K_{R}\right]_{e}\left\{\phi^{(i)}\right\}_{0} / \sum_{e-1}^{e \max }\left\{\phi^{(i)}\right\}_{0}^{\mathrm{T}}\left[K_{R}\right]_{e}\left\{\phi^{(i)}\right\}_{0}$ は $i$ 次振動モードで変形した条件での各要素の歪みエネルギー 分担率 (要素e の歪みエネルギー/全系の歪みエネルギ一) である. $\left\{\phi^{(i)}\right\}_{0}$ は実固有モードで式 (17) から求められ, 式 (17) から共振周波数 $\omega^{(i)} / 2 \pi \simeq \omega_{0}^{(i)} / 2 \pi$ が求められる.式 （19）からモード損失倸数 $\eta_{\text {tot }}^{(i)}$ は材料減衰 $\eta_{e}$ と歪みエネル ギー分担率 $S_{e}^{(i)}$ との積の全要素にわたる和から近似計算で きる.ここで, $\eta_{e} S_{e}^{(i)}$ は各要素の散晩エネルギーの分担量 に相当し，これが大きい要素ほどモード損失係数 $\eta_{\text {tot }}^{(i)}$ への 影響が大きい場所となる.なお,この減衰特性の近似計算 式は先に著者らが粘弾性体と弾性体を組み合わせた構造の 振動減衰を解析するために導出したものと同様な形式で, 微小変形条件のもとでの実験や理論解との検証がなされて
いる ${ }^{(4)}$.また, 式 (19) は, Johnson らが開発したモード歪 みエネルギー法 ${ }^{(5)}$ とも結果的に同じ形式になっている.

3.5 非線形離散化方程式の基準座標への変換 式 (11) のような物理座標系で記述された運動方程式は自由度が大 きく, 直接計算すると膨大な時間が必要となる.そこで, 式 (11) に線形固有振動モードに対応する基準座標を導入 し, 自由度を縮小する.ただし，線形固有振動モード $\left\{\phi^{(i)}\right\}$ は3 章 4 節の $\left\{\phi^{(i)}\right\}_{0}$ で $\left\{\phi^{(i)}\right\} \simeq\left\{\phi^{(i)}\right\}_{0}$ と近似できるものと する. この $\left\{\phi^{(i)}\right\}_{0}$ に対応する基準座標 $b_{i}$ を導入し, 変位 $\{u\}$ を $b_{i}$ で 次式のように記述する.

$\{u\}=\sum_{i=1}^{i} \tilde{b}_{i} \frac{1}{n_{i}}\left\{\phi^{(i)}\right\}_{0}$

ただし,

$$
\begin{aligned}
& \left\{\phi^{(i)}\right\}_{0}=\frac{1}{n_{i}}\left\{\hat{\phi}^{(i)}\right\}_{0}, \quad n_{i}=\frac{1}{\sqrt{m_{i}}}, \\
& m_{i}=\left\{\phi^{(i)}\right\}_{0}^{\mathrm{T}}[M]\left\{\phi^{(i)}\right\}_{0},\left\{\hat{\phi}^{(i)}\right\}_{0}^{\mathrm{T}}[M]\left\{\hat{\phi}^{(i)}\right\}_{0}=1
\end{aligned}
$$

である.

式 (20) を式 (11) へ代入し， $\left\{\hat{\phi}^{(i)}\right\}$ の直交性を利用し て整理すると, 基準座標系での全亲の離散化運動方程式と して次式を得る。

$$
\begin{aligned}
& M\left(\tilde{b}_{i}\right) \equiv \ddot{\tilde{b}}_{i}+\eta_{\mathrm{tot}}^{(i)} \omega^{(i)} \dot{\tilde{b}}_{i}+\left(\omega^{(i)}\right)^{2} \tilde{b}_{i}+\sum_{j} \sum_{k} \tilde{D}_{i j k} \tilde{b}_{j} \tilde{b}_{k} \\
& +\sum_{j} \sum_{k} \sum_{T} E_{i j k l} b_{j} b_{k} \bar{b}_{I}-P_{i}=0 \cdots \cdots
\end{aligned}
$$

また, $\hat{\phi}_{\alpha i x}$ は非線形集中ばねー粘弾性ブロックの接合節点 $\alpha$ における $x$ 方向の $i$ 次固有べクトル $\left\{\tilde{\phi}^{(i)}\right\}$ の成分である.

式 (21) は線形固有振動形に対応した基準座標 $\tilde{b}$ につい ての非線形連立三次常微分方程式である. なお, 式 ${ }^{j}(21)$ 中 の右辺第 2 項の減衰項であるが, 定式化の過程で式 (19) と同じ形が得られ; 無理なく式 (21) にモード損失係数 $\eta_{\text {tot }}^{(i)}$ を導入できていることを付記しておく.

また, $\eta_{\text {tot }}^{(i)}$ は微小変形条件の歪みエネルギーから式 (19) により求めている.非線形集中ばねについては微小変形で はないので非線形ばね定数 $\gamma_{2} ， \gamma_{3}$ が線形ばね定数 $7_{1}$ より も充分に小さいという弱非線形性の仮定が本解析法を用い るうえで必要となる.

基準座標 $\tilde{b}$ についての式 (21) により, 物理座標での離 散化方程式 $(11)$ に比べ, 大幅に計算に必要な自由度を削 減できる.後述する数值計算例では, 物理座標では 15,504 自由度であったが, 基準座標では 20 自由度程度の計算と なっている.

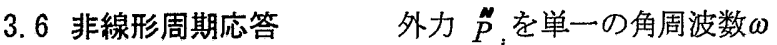
による加振力であると仮定する。すなわち式 (21) 中の $\{f\}$ は $\{f\}=\left\{P_{d}\right\} \cos \omega t$ となる. 加振振幅 $\left\{P_{d}\right\}$ は加振位置 に対応する節点 $\alpha$ で加振方向の成分のみ非ぜロとなる。 こ の場合の周期応答を求めるため, 対応する解を次式で仮定 する.

$$
\begin{aligned}
\tilde{b}_{i}= & C_{i 1 \mu_{\mathrm{o}}}+\sum_{p}\left[C_{i 1 \mu p} \cos (\mu p \omega t)\right. \\
& \left.+C_{i 2 \mu_{p}} \sin (\mu p \omega t)\right] \cdots \cdots \cdots
\end{aligned}
$$

$(i, p=1,2,3, \cdots)$

なお， $C_{i 1 \mu p}, C_{i 2 \mu p}(i, p=1,2,3, \ldots)$ は末定倸数である. 主共振や高調波共振応答を求めるには $\mu=1$ とおき, 分数 次調波共振応答では, $\mu=1 / n$ （ $n$ : 整数）を用いる.式 
（22）を式 (21) に代入し，調和バランス法を適用すると， つぎの条件式を得る.

$$
\begin{aligned}
& \frac{\mu s \omega}{2 \pi} \int_{0}^{\frac{2 \pi}{\mu s \omega}} M\left(\tilde{b}_{i}\right) \cos (\mu p \omega t) d t=0,(s=0,1,2 ; \cdots) \\
& \frac{\mu s \omega}{2 \pi} \int_{0}^{\frac{2 \pi}{\mu s \omega}} M\left(\tilde{b}_{i}\right) \sin (\mu p \omega t) d t=0,(s=1,2,3, \cdots) \cdots(2)
\end{aligned}
$$

上式より得られる $C_{i 1 \mu p}, C_{i 2 \mu p} \quad(i, p=1,2,3, \ldots)$ に関す る連立三次方程式をニュートンラプソン法で解くと, 共振 応答の周期解を得る. 評価点 $\xi$ における応答振幅の $x$ 方向成 分の実効值 $W$ ms 忺式 (24) 加求められる.

$$
\begin{aligned}
& W_{\mathrm{rms}}=\left\{(1 / 2) \sum_{p}\left[\left(\sum_{i} C_{i 1 \mu p} \frac{1}{n_{i}} \Phi_{\xi i x}\right)^{2}+\left(\sum_{i} C_{i 2 \mu p} \frac{1}{n_{i}} \Phi_{\xi i x}\right)^{2}\right]\right. \\
& \left.+\left(\sum_{i} C_{i 2 \mu 0} \frac{1}{n_{i}} \phi_{\xi i x}\right)^{2}\right\}^{1 / 2} \ldots \ldots \ldots \ldots \ldots \\
& (i=1,2,3, \cdots, p=1,2,3, \cdots)
\end{aligned}
$$
応する固有べ㘶トルの $x$ 方向成分である.

\section{4. 計算結果}

\section{1 計算方法の検証}

提案法について解析法と開 発プログラムを検証し, 他の解析方法で解が得られる条件 での結果を比較する. 具体的には, 1. 微小振幅の条件と 2 . 剛体ブロック+非線形集中ばねの条件で検証を行う。

以降の計算では，非線形集中ばねのばね定数は $\gamma_{1}$ $=980[\mathrm{~N} / \mathrm{mm}], \gamma_{2}=0\left[\mathrm{~N} / \mathrm{mm}^{2}\right], \gamma_{3}=9.8\left[\mathrm{~N} / \mathrm{mm}^{3}\right]$ と弱非線形 の条件とした，また, 式 (17) の固有值計算にはサブスペー ス法を用いた. 以降, 記号 $(i, j)$ により共振応答を分類した. $i$ は誘起される $i$ 次の振動モードを表す. $j$ は共振応答の種 類で $j=1$ は主共振, $j=1 / 3$ は $1 / 3$ 次分数次調波共振. $j$ $=3 / 1$ は 3 倍の高調波共振に対応した応答となる.

(1) 微小振幅条件下での検証提案 FEM では, 式 （17）で求めた固有モードを基準座標とする運動方程式 （21）を用いて、非線形振動応答の計算効率を高めている. したがって非線形振動応答の計算精度に線形固有モードの 精度が影響する.そのため, 汎用の線形FEM (NASTRAN) で 得られる共振周波数, 線形固有振動モード, モード損失係 数と式 (17) から得られる共振周波数 $\omega^{(i)} / 2 \pi(i=1,2$, $3, \ldots)$, 線形固有振動モード $\left\{\boldsymbol{\phi}^{(i)}\right\} ;(i=1,2,3, \ldots)$, モ一 ド損失係数 $\eta_{\mathrm{tot}}^{(i)}(i=1,2,3, \ldots)$ を比較した. 集中ばねの材 料損失係数を $\eta_{s}=0.01$, ブロックの材料損失係数を $\eta_{b}=0.2$ としてモード損失計数 $\eta_{\mathrm{tot}}^{(i)}$ を式 (19) から求めた.

まず, 線形固有振動モード $\left\{\tilde{\phi}^{(i)}\right\}$ を図 3 に記載する. $\left\{\tilde{\phi}^{(i)}\right\}$ は提案 FEM と NASTRAN でよく一致していたため, 提案FEM の結果のみを示す.Mode1 の図中の矢印は, 非線形集中ば ねが主体に変形し,ブロックが矢印の方向 $(x$ 方向) に剛体 に近い運動をすることを表す. 2 次以上の高次のモードは
ブロックの弾性モードになっている.なお, Mode5 と Mode10 は緹波による共振の振動モードである.

各次数のモード損失係数 $\eta_{\mathrm{tot}}^{(i)}$ と共振周波数 $\omega^{(1)} / 2 \pi$ を図 4 に示す. 提案 FEM の結果と NASTRANの結果はよく一致し た. なお, 図中にあるNASTRANによる $\eta_{\mathrm{tot}}^{(i)}$ の值は, 各要素の 歪みエネルギー分担率 $S_{\mathrm{c}}^{(i)}$ をNASTRAN で計算し, 式 (19) を, 別途作成したプログラムで計算したものである.

これらのパラメータを用いて, 微小振幅条件のもとでの 共振応答を式 (22), 式 (23), 式 (24) による提案 FEM+ 調 和バランス法で求める. その結果と次式の線形のモード重 ね合わせ法 ${ }^{(6)}$ で求めた共振応答を比較し検証する。

$$
w=\bar{w} \cos \omega t
$$$$
\bar{w}=\sum_{i=1} \phi_{\xi i x} \phi_{\zeta i x} p_{d} /\left(\left(\omega^{2}-\left(\bar{\omega}^{(i)}\right)^{2}\right)+j \eta_{\mathrm{tot}}^{(i)}\left(\bar{\omega}^{(i)}\right)^{2}\right)
$$

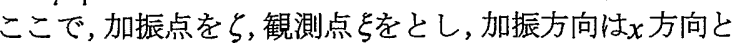

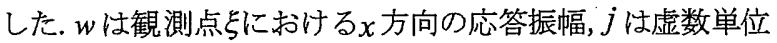
である.また, $\tilde{\phi}_{\zeta i}$ は $i$ 次固有べクトル $\left\{\tilde{\phi}^{(i)}\right\}$ の加振節点 $\zeta$ に対応する $x$ 方问成分である. $\hat{\phi}_{\xi i .}$ は先に示したように $\left\{\hat{\phi}^{(i)}\right\}$ 観測点 $\xi に$ 対応する $x$ 方向成分である. 単一の角周 波数 $\omega に よ り$ 励振を受ける場合の線形応答の検証問題なの で, $w$ の実効值 $W$ ms は, 次式 (26) から求められる.

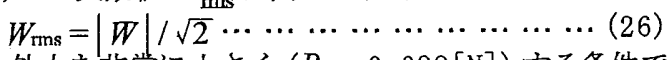

外力を非常に小さく $\left(P_{d}=0.098[\mathrm{~N}]\right)$ する条件で, 提案 FEM と調和バランス法により求めた応答と式 (25)による 応答を比較する. 図 5 に 20 モード近似での結果を示す. 図 より,両者は各共振ピークが減衰される様子など,よく一 致している.

（2）ブロックが剖体の条件下での検証＼cjkstart粘弾性ブロッ クを集中質量に置き換え,集中質量一非線形集中ばね系 （1 自由度質量ばね系）で非線形周期応答を求めた. 具体的 には, 次式 (27) を Runge-Kutta-Gil1 法で直接積分 し時 刻歷を求め, 実効値を計算し共振応答を求めた.

$m \ddot{w}=-\left(\bar{\gamma}_{1} w+\gamma_{2} w^{2}+\gamma_{3} w^{3}\right)-C \dot{w}+F \ldots$ (27)

ここで, $m$ は弾性ブロックの質量を集中質量に置き換え た量である. $w$ は質量の変位, $F$ は質量に作用する外力で $F=p_{d} \cos \omega t$ とした. $p_{d}$ は周期外力の振幅である. 減衰定数 は $C=\eta_{s}\left(m \bar{\gamma}_{1}\right)^{1 / 2}$ から求めた.

この結果と提案 FEMにおいてブロックのヤング率 $E$ を非 常に大きくした場合 $\left(E=10^{5}[\mathrm{GPa}]\right)$ の共振応答の計算結 果を比較した。提案FEMによる応答の計算には, 先に述べ た調和バランス法を 1 モード近似で用い, 加振位置と観測 位置は非線形集中ばねとブロックの接合節点 $\alpha$ とした. 集 中ばねの材料損失係数を $\eta_{s}=0.01$, ブロックの材料損失係 数を $\eta_{s}=0.1$ とした.これらの条件では式 (19) から系の

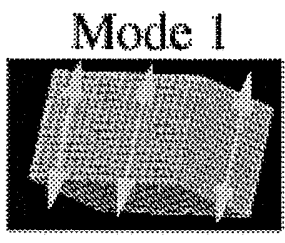

Mode 6

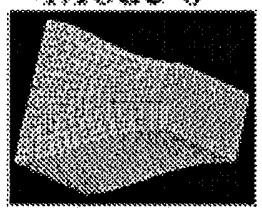

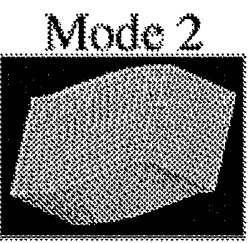

Mode 7

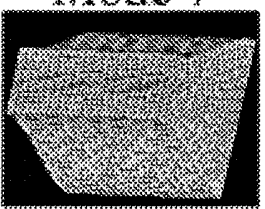

Fig.3 Verification of Proposed method (Vibration mode)
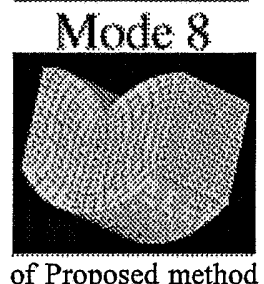
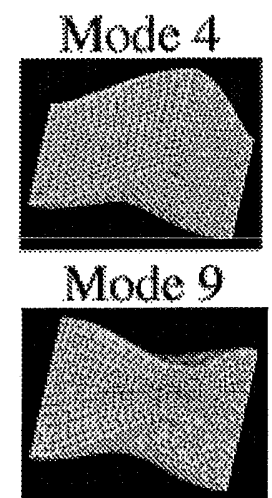

Mode 10

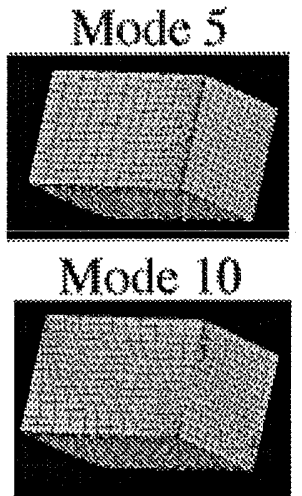


モード損失係数は $\eta_{\mathrm{tot}}^{(i)}=0.01$ になる. 式 (21) の外力項 $\tilde{P}_{P}^{N}=n_{\left\{\tilde{\phi}^{(i)}\right.}{ }^{\mathrm{T}}\{f\}$ 中の $\{f\}$ について, 加振節点 $\alpha$ に対応する $x$ 方向成分の始 $P_{d} \cos \omega t$ 与え, 他の成分はゼロとした。 こで 1 次共振は図 3 の Mode1に対応しており, 弾性ブロッ クを質量とし, 非線形集中ばねが主体に変形するモードで ある.このモードは式 (27) の集中質量一非線形集中ばね 系 (1 自由度質量げね系) で現れる振動モードと対応する。 その系での応答の計算結果と, 提案 FEM でブロックのヤン グ率を非常に大きくした剛体ブロックの場合 $\left(E=10^{5}[\mathrm{GPa}]\right)$ の応答の計算結果を比較した, 結果を図 6 に示す, 横軸を加振周波数 $\omega /(2 \pi)[\mathrm{Hz}]$, 縦軸を変位の実効 值 $W_{\mathrm{mms}}$ [mm]とした. 非線形集中ぼねの影響が現れるまで 加振力を大きくした条件 $\left(P_{\mathrm{d}}=9800[\mathrm{~N}]\right)$ を用いた. 図より, 両者の結果はピークの高さ, ピーク周波数ともによく一致 している.これより, 剛体ブロックの条件で, 提案 FEM とプ ログラムが検証できた。

以上のように，提案法は微小振幅条件や剛体ブロック条 件で, 従来の解析法の結果と一致し検証できた.

\section{2 ブロックの応答に及ぼすヤング率の影響}

つぎに粘弾性ブロックのヤング率 $E$, 材料損失係数 $\eta_{b}$ が 減衰振動に与える影響を調べる。

(1) 振動モード ヤング率 $E$ を $1 \mathrm{GPa}$ から $210 \mathrm{GPa}$ で変化させた場合の振動モード $\left\{\phi^{(i)}\right\}$ 。 は, 先に示した図 3 とマクロでは変化はなかった.

（2）モード損失係数，共振応答とブロックのヤング率の関 係 粘弾性ブロックのヤング率 $E$ が異なる場合の 1 次 モード (非線形集中ばね主体の振動モード) の減衰 $\eta_{\text {(1) }}^{(1)}$ 比較する.図 7 にブロックと集中ばねの歪みエネルギ一分 担率 $S_{\mathrm{b}}^{(1)}, S_{\mathrm{s}}^{(1)}$ を示す. $S_{\mathrm{b}}^{(1)}$ はブロックに対応する要素を $e_{\mathrm{b}}$, その総数を $e_{\mathrm{b} \text { max }}$ とすると次式で求められる.

$$
S_{\mathrm{b}}^{(1)}=\sum_{e_{\mathrm{b}}=1}^{e} S_{e_{\mathrm{b}}}^{(1)}
$$

ヤング率が小さい場合は, 集中ばねが接続されている部 分（節点 $\alpha$ ) のブロックが弾性変形することが振動モード $\left\{\phi^{(1)}\right\}_{0}$ の観察からわかっている.したがって, 図7 のよう に,ブロックのヤング率が小さくなると,ブロックの歪み エネルギ一分担率 $S_{\mathrm{b}}^{(1)}$ が高くなるかわりに非線形集中ばね

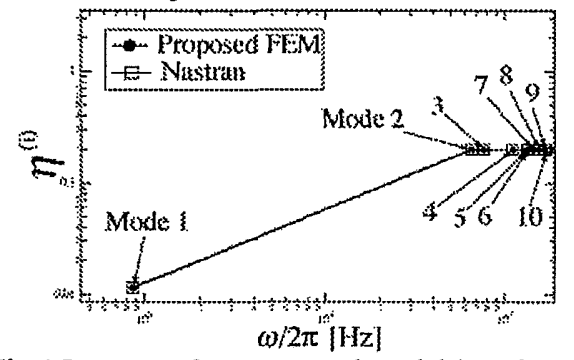

Fig.4 Resonant frequency and modal loss factor

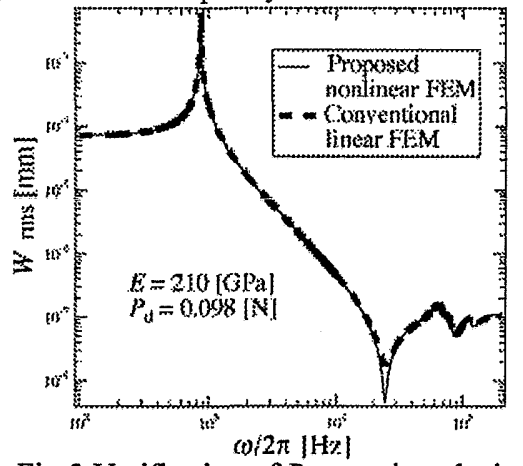

Fig.5 Verification of Proposed method (response under infinitesimal displacement)
の歪みエネルギ一分担率 $S_{\mathrm{s}}^{(1)}$ が低くなる.一方, 式 (19)よ り，モード損失係数 $\eta_{\text {tot }}^{(1)}$ は, 各要素の歪みエネルギー分担 率 $S_{\mathrm{c}}^{(1)}$ と, 要素の材料減衰の積 $\eta_{e} S_{e}^{(1)}$ の全要素の総和で近 似できる.すなわち, 集中ばねの材料損失係数 $\eta_{s}$ が粘弾性 ブロックの材料損失你数 $\eta_{b}$ より小さい条件 $\left(\eta_{s}=0.01\right.$, $\eta_{b}=0.2 ）$ を考えると,ブロックのヤング率 $E$ が大きいほど, ばねの歪みエネルギー分担率 $S_{\mathrm{s}}^{(1)}$ が高くなり，その結果, 図 8 のように 1 次モードの減衰 (モード損失係数 $\eta_{\text {tot }}^{(1)}$ ) が小 さくなる現象が起こる.

$\eta_{s}=0.01 ， \eta_{b}=0.2$ の条件でヤング率 $E$ が $210 \mathrm{GPa}$ と $1 \mathrm{GPa}$ の場合の共振応答を図 9 (a) と図 9 (b) にそれぞれ示 す.調和バランス法による応答の近似モード数は $I c=20$ と した. 横軸を加振周波数 $\omega /(2 \pi)[\mathrm{Hz}]$, 縦軸を図 1 の観測 点の変位の実效值 $W_{\mathrm{ms}}[\mathrm{mm}]$ とした。また, 外力 $P_{d}$ を $P_{d}$

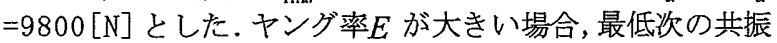
忘答曲線 $(1,1 / 1)$ が漸硬型となる.さらに, 最低次の共振 の 3 倍高調波共振 $(1,3 / 1)$ と $1 / 3$ 分数次調波共振 $(1,1 / 3)$ が新たに現れる.ヤング率 $E$ が小さい場合，この 条件では先ほど述べたように 1 次モードの減衰 (モード損 失係数 $\left.\eta_{\text {1) }}^{(1)}\right)$ が大きくなり, 最低次の共振の 3 倍高調波共 振 $(1,3 / 1)$ がジャンプしなくなるとともに $1 / 3$ 分数次調 波共振 $(1,1 / 3)$ が認められなくなる.

観測点を, 粘弾性ブロックの底面の一角 (観測点 $\xi$ ) だ けでなく,ブロックと非線形集中ばねの接合節点（観測点 $\alpha$ ）とした場合も計算した.ブロックの材料損失倸数を

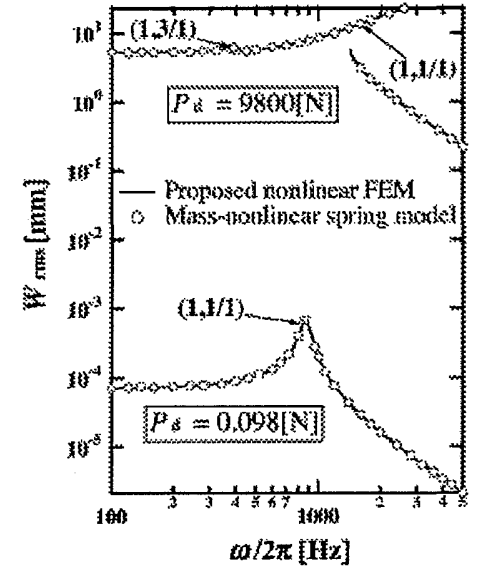

Fig.6 Verification of proposed method for rigid block

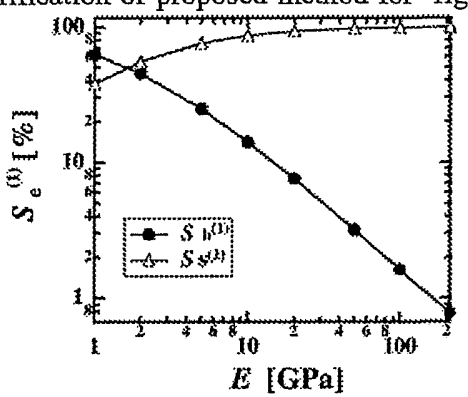

Fig.7 Effect of Young's modulus on share of strain energy

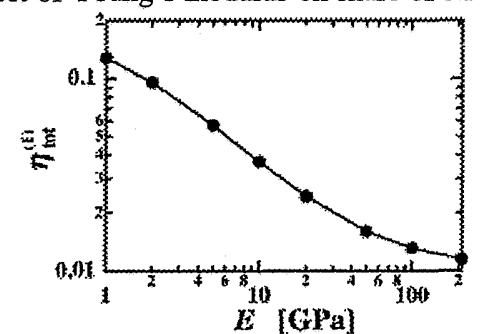

Fig.8Effect of Young's moduluson modal loss factor 
$\left(\eta_{b}=0.2\right)$, 集中ぼねの材料損失係数を $\left(\eta_{*}=0.01\right)$ とした. ブロックのヤング率が異なる場合（ $E=1[\mathrm{GPa}]$, $E=210[\mathrm{GPa}])$ の共振応答を求め, 図 10 (a) と図 $10(\mathrm{~b})$ に それぞれ示す。最低次モードでは，ヤング率が $1 \mathrm{GPa}$ の場 合, ブロックと集中ばねの接合節点 $\alpha$ が弾性変形するため に二つの観測点 $\alpha$ と $\xi$ 間の変位に差があるが, ヤング率が $210 \mathrm{GPa}$ の場合では，接合節点 $\alpha$ が弾性変形しにくくなり， ヤング率が $1 \mathrm{GPa}$ の場合と比べ, 観測点 $\alpha$ と $\xi$ 間の変位に 差がない. $\mathrm{x}$ 方向並進以外の剛体モードはガイドで拘束し ているので,この差は弾性変形によるものといえる.

近似モード数 $I_{c}$ を変化させて共振応答を求めた. 図 11 (a) と図 11 (b) に, ヤング率を $E=210, E=1$ [GPa] とし た結果を示す. 図中, $I_{c}=1, I_{c}=2, I_{c}=5, I_{c}=10, I_{c}=20$ の 条件での結果が示されている.ブロックの材料損失係数を $\left(\eta_{b}=0.2\right)$, 集中ぼねの材料損失倸数を $\left(\eta_{s}=0.01\right)$ とし た。粘弾性ブロックのヤング率が大きい場合（ $E=210$ [GPa], 図 $11(\mathrm{a}))$ には, $I_{c}=1$ と $I_{c}=20$ を比較しても, 変位 に大きな差は現れない.よって,ヤング率 $E$ が大きい場合， 少数の近似モ一ド数 $I_{c}$ での計算が可能といえる.一方, ヤ ング率 $E$ が小さい場合 $(E=1[\mathrm{GPa}]$, 図 $11(\mathrm{~b}))$, 近似モード 数 $I_{c}$ が多くなるほど, 非線形の応答振幅が徐々に大きくな る.この場合, 近似モード数 $I_{c}$ は 20 以上必要である。

図 12 に図 11 中の 1 次振動モードに含まれる各振動モー ドの振幅成分を大きい順に 15 成分記載した.これより式 (21) 中の非線形項 $\tilde{D}_{i j k}, \hat{E}_{i i k j}$ に起因するモード連成を調 べることが可能である. 図の縦軸は応答の実効值 $W_{m m s}$ への 各モードの寄与率, 横軸は振幅成分への大きさの順位であ る. 図中の記号 $[x, y] z$ の $x$ は振動モードの次数, $\mathrm{y}=1 / 1$ は 基本調波成分, $\mathrm{y}=3 / 1$ は 3 倍高調波成分を表す. $\mathrm{z}$ の籄所 が無表記のものは式 (22) の cos 成分, s の表記のあるも のは $\sin$ 成分に相当することを表す. 加振周波数 $\omega / 2 \pi$ は 1 次の共振周波数 $\omega^{(1)} / 2 \pi$ と一致する条件とし, 近似モ一ド 数は $I_{c}=20$ とした. 図から,ブロックの材料損失係数が大 きい場合 $\left(\eta_{b}=0.2\right.$, 図 $\left.12(\mathrm{~b})\right), 1$ 次モードの基本調波 $(1,1 / 1)$ の $\sin$ 成分と 3 倍高調波 $(1,3 / 1)$ の $\sin$ 成分の 寄与は, ブロックの材料損失係数が小さい場合 $\left(\eta_{b}=0.02\right.$,

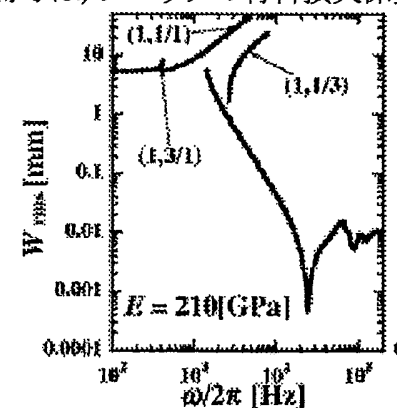

(a)

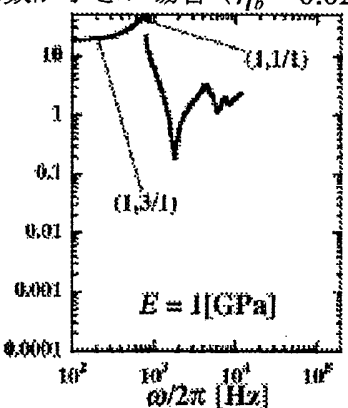

(b)
Fig.9 Effects of Young's modulus on resonance response

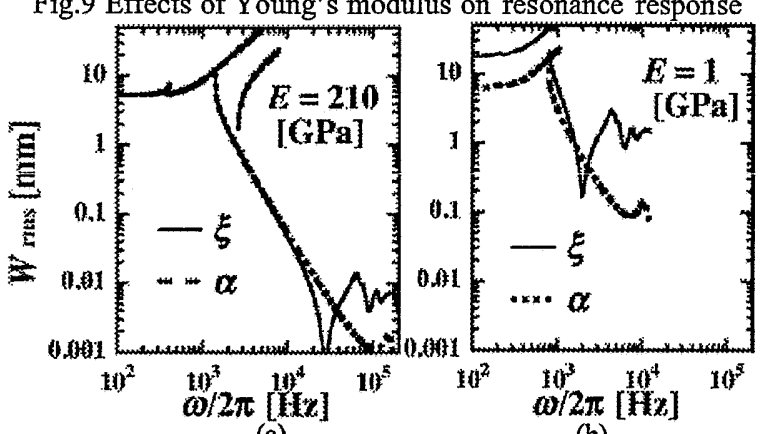

(a)

(b)

Fig.10 Effects of Young's modulus on resonance response

図 12 (a)) よりも大きい, sin 成分は, $\cos$ 成分の加振力に 対し, 位相遅れの成分である. すなわち, 加振力と変位の関 係にヒステリシスを有するようになっている.ヒステリシ ス成分が大きい程, 減衰効果が大きくなるため, ブロック の材料損失係数が大きい程, 非線形共振応答は制振される.

\section{5. 結言}

非線形集中ばねで粘弾性ブロックを支持し，鉛直方向の 周期加振力を加え動的态答を解析した. 運動方程式を, 線 形固有振動形を基準座標とする三次の非線形連立常微分方 程式に変換し, 計算自由度を縮小した運動方程式に調和バ ランス法を適用し非線形共振応答を求めた。

集中ばねの材料損失係数がブロックの材料損失係数より 小さい場合, ブロックのヤング率が小さくなると,ばね変 形主体の振動モードにブロックの弾性変形が含まれ, モー ド損失係数が大きくなる. その減衰増大の効果により, 対 応するモードの高調波共振応答と分数次共振応答の発生が 抑制される。

\section{参 考 文 献}

（1）山口, 永井, 丸山, 油田, 機論 69-688C (2003), 3167-3174.

（2）Zienkiewicz, 0.C. 著, 吉識雅夫ほか訳, マトリッ クス有限要素法, (1970), 倍風館.

（3）笉津久一郎, 宮本博, 山田嘉昭, 山本善之, 川井 忠彦, 有限要素法ハンドブック I 基礎編,

（1981），1-427，倍風館.

（4）山口誉夫, 黒沢良夫, 松村修二, 野村章, 機論 6 9678C (2003) 297-303.

(5) Johnson, C. D., and Kienholz, D. A., AIAA Journal, 2 0-9, (1982), 1284-1290.

（6）長松昭男, モード解析, (1985), 倍風館.

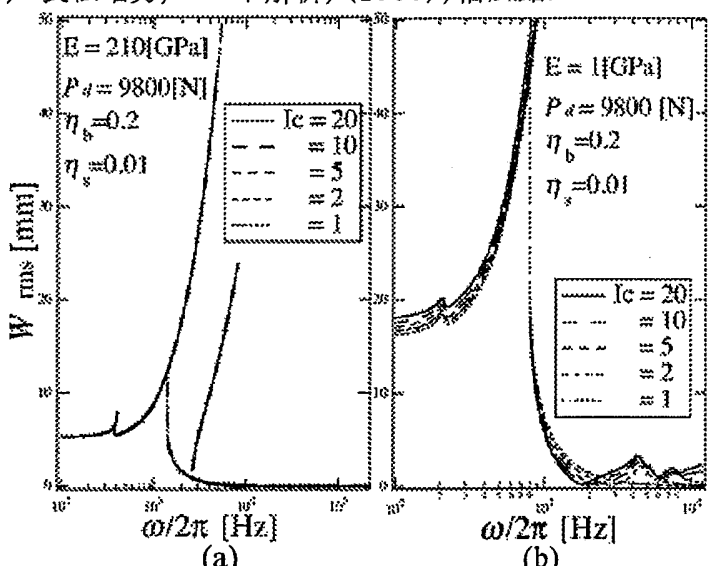

(a)

(b)

Fig.11 Effects of assumed vibration modes on nonlinear

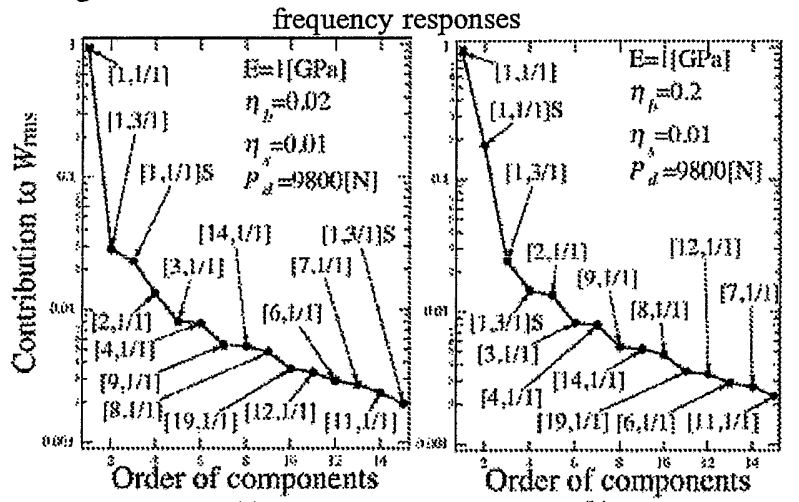

(a)

(b)

Fig.12 Effects of assumed vibration modes on nonlinear frequency responses 